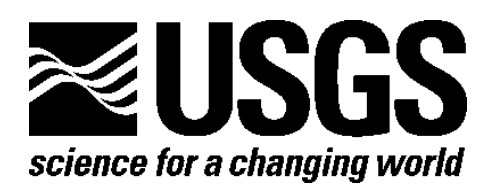

\title{
Developing a Vision: Incorporating Ecosystem Services into Decision Making_Proceedings of a Workshop
}

By Dianna Hogan, Greg Arthaud, Iris Goodman, Malka Pattison, Roger Sayre, Carl Shapiro, and Bea Van Horne

Proceedings of a workshop associated with

A Conference on Ecosystem Services (ACES 2008)

April 15, 2008

Open-File Report 2009-1062

U.S. Department of the Interior

U.S. Geological Survey 


\section{U.S. Department of the Interior \\ KEN SALAZAR, Secretary}

\section{U.S. Geological Survey \\ Suzette M. Kimball, Acting Director}

U.S. Geological Survey, Reston, Virginia: 2009

For product and ordering information:

World Wide Web: http://www.usgs.gov/pubprod

Telephone: 1-888-ASK-USGS

For more information on the USGS-the Federal source for science about the Earth,

its natural and living resources, natural hazards, and the environment:

World Wide Web: http://www.usgs.gov

Telephone: 1-888-ASK-USGS

Suggested citation:

Hogan, Dianna, Arthaud, Greg, Goodman, Iris, Pattison, Malka, Sayre, Roger, Shapiro, Carl, and Van Horne, Bea, 2009, Developing a Vision: Incorporating Ecosystem Services into Decision Making—Proceedings of a Workshop: U.S. Geological Survey Open-File Report 2009-1062, 8 p.

Any use of trade, product, or firm names is for descriptive purposes only and does not imply endorsement by the U.S. Government.

Although this report is in the public domain, permission must be secured from the individual copyright owners to reproduce any copyrighted material contained within this report. 


\section{Contents}

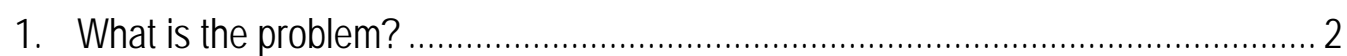

2. What would have to happen ecologically and geographically to make ecosystem services routinely and effectively used in decision making? ................. 2

3. What would have to happen socioeconomically to make ecosystem services routinely and effectively used in decision making? ............................................. 3

4. What would have to happen institutionally to make ecosystem services routinely and effectively used in decision making? ............................................... 4

5. What would change if ecosystem services were routinely and effectively considered in conservation, restoration, resource management, and development decisions?

6. Synthesis-How can ecology, economics, and geography be integrated so that ecosystem services are routinely and effectively used in decision making? .....5

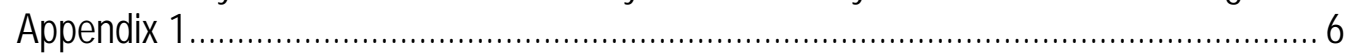




\title{
Developing a Vision: Incorporating Ecosystem Services into Decision Making_-Proceedings of a Workshop
}

\author{
By Dianna Hogan¹, Greg Arthaud², Iris Goodman³, Malka Pattison4, Roger Sayreㄹ, Carl Shapiro¹, \\ and Bea Van Horne ${ }^{1}$ \\ Hosted by the MIT-USGS Science Impact Collaborative (MUSIC) \\ Massachusetts Institute of Technology (MIT), Cambridge, MA \\ April 15, 2008
}

In association with

A Conference on Ecosystem Services (ACES)

ACES 2008: Using Science for Decision Making in Dynamic Systems

\section{Summary Report 5}

The production, location, use, and value of ecosystem services have become an important factor in resource management. Decisions relating to resource conservation and restoration, as well as development, require an understanding of the services provided by natural systems and the response of these systems to natural and human-induced change. Increased demands for development and the resulting pressures on ecosystem services have lent urgency to the need for an improved understanding of the value of natural capital. However, resource management decisions are often made without considering the importance and value of services resulting from natural systems.

This report summarizes the first of three preconference workshops associated with ACES 2008 (A Conference on Ecosystem Services): Using Science for Decision Making in Dynamic Systems. This workshop explored how information on ecosystem services can be incorporated more effectively into conservation, restoration, resource management, and development decisions. Attendees developed a vision for a world in which ecosystem services information is included routinely and effectively in decision making. Here we provide a synthesis of the discussion at workshop 1, which was organized around the following questions: (1) What is the problem? (2) What would have to happen ecologically

\footnotetext{
${ }^{1}$ U.S. Geological Survey, Reston, VA.

${ }^{2}$ U.S. Forest Service, Washington, DC.

${ }^{3}$ U.S. Environmental Protection Agency, Washington, DC.

${ }^{4}$ U.S. Department of the Interior, Washington, DC.

${ }^{5}$ The ideas presented in this report are based on contributions from participants at the workshop. Workshop participants are listed in Appendix 1.
} 
and geographically to make ecosystem services routinely and effectively used in decision making?

(3) What would have to happen socioeconomically to make ecosystem services routinely and effectively used in decision making? (4) What would have to happen institutionally to make ecosystem services routinely and effectively used in decision making? (5) What would change if ecosystem services were routinely and effectively considered in conservation, restoration, resource management, and development decisions? (6) Synthesis-How can ecology, economics, and geography be integrated so that ecosystem services are routinely and effectively used in decision making?

\section{What is the problem?}

Ecosystem services are routinely produced in natural and managed systems. However, ecosystem and resource management, conservation, restoration, and development decisions are often made without considering ecosystem services or with imperfect information on the decisions' possible impacts on the services. As a result, ecosystem services may be unexpectedly degraded, with significant monetary and non-monetary costs to society. The reasons that ecosystem services are not routinely considered in decision making can be grouped into four fundamental categories: (1) ecological, (2) geographic, (3) socioeconomic, and (4) institutional.

Ecological. We do not have an adequate understanding of the ecological processes that produce ecosystem services. In addition, we acknowledge that there may be currently unrecognized or unutilized processes. Understanding the biophysical processes helps to predict the ecological effects of human and natural actions, both beneficial and detrimental, on the production of ecosystem services and is essential to evaluating management alternatives.

Geographic. We do not fully understand the spatial and temporal dimensions of ecosystem service production, use, and values. Decisions made locally affect natural capital and services production elsewhere. Decision makers may not be aware of or concerned with the regional or global impact.

Socioeconomic. We do not have adequate information on the monetary and non-monetary value of ecosystem services; we do not know how to value ecosystem services in dollars, or in social values or cultural terms. This leads to decisions that do not always consider the impact to ecosystem services, resulting in unexpected economic, social, or cultural repercussions, as well as shifting costs to future generations, other regions, or other stakeholders.

Institutional. Institutional processes, structures, and instruments do not adequately facilitate the routine consideration of ecosystem services in decision making. In some cases, the ecosystem services are public goods, with property rights and externalities that impede the creation of markets and incentives for providing ecosystem services. The problem is less likely to exist for certain ecosystem goods, such as food, fiber, and fuel, which have established markets.

\section{What would have to happen ecologically and geographically to make ecosystem services routinely and effectively used in decision making?}

Spatially explicit ecosystem service analyses that integrate ecology, economics, and geography are necessary to understand and communicate the value, distribution, and interrelationships between ecosystem services and beneficiaries. Knowledge of the types and distributions of ecosystem services on the landscape is essential for assessing the value of ecosystem services, identifying the opportunities and 
tradeoffs of alternative management actions, and providing a framework for evaluating future changes in climate, demography, and other drivers of change.

Decision makers might consider environmental, economic, and social tradeoffs when making conservation, resource management, restoration, and development decisions. These decisions require the ability to visualize the spatial configuration of ecosystem services and those that produce and benefit from them. Understanding how ecosystem services are co-located on the landscape will help identify interrelationships between different ecosystem services (forest product production versus water quantity and quality regulation), and how these interrelationships affect economic and social objectives. Another important consideration is scale. Decision makers often focus at the local level and on the near term. Ecosystem service production may not respond as quickly to changes. Also, producers and beneficiaries tend to extend beyond local jurisdictions. Multiscale analyses provide a better understanding of the tradeoffs of alternative proposals on the production of ecosystem services.

Geospatial analysis also improves our understanding of the cause and effect of human and natural actions on the production of ecosystem services. The ability to map the production, flow, consumption, or value of ecosystem services will require accurate geospatial accounting of which ecosystem services are provided by which ecosystems. It is also critical to identify the spatial and temporal scales at which those services are being produced and used, and the opportunities and threats to their continued existence. Further, the use of standardized definitions, classifications, and ecosystem maps will facilitate the effective use of ecosystem services in management and decision making. A better understanding of the geospatial units at which the services are provided would improve our ability to identify, measure, and value them.

\section{What would have to happen socioeconomically to make ecosystem services routinely and effectively used in decision making?}

The public values the freedom to use natural resources, but at the same time may reject the notion of paying for their use-and the very concept of applying economic values to ecosystem services may be perceived as contrary to some. More research is needed on intrinsic values, human behavior in relation to incentives, and the impact of ecosystem services information on behavior/motivation.

Beyond valuation, we should be concerned with trade-offs, identifying ways to determine prices or valuation, the costs of technological alternatives, understanding the measurement of both outputs and risk, exploring the economic implications of linkages between services, understanding values as a method of ranking choices, and the needs of existing Federal processes and regulations. Economic concepts will be useful in designing conservation strategies and creating institutions that align incentives with ecosystem service values. In addition, research is needed to understand how services with public good characteristics, or which have externalities, can be more effectively priced and considered in decisions. Additional research is needed in understanding decision making under uncertainty and how processes such as adaptive management can be applied.

To advance the use of ecosystem services information in decision making, we need to focus on providing information that is most relevant to the public and to decision makers. The development of improved models and tools to integrate the natural and social sciences is also needed. 


\section{What would have to happen institutionally to make ecosystem services routinely and effectively used in decision making?}

As is the case with geographic scales, there is no ideal institutional hierarchy or scale to facilitate the use of ecosystem services in decision making. Institutions will vary in both hierarchy and scale to accommodate the issues and the instruments selected to address them. Seemingly small-scale issues may, in fact, benefit from approaches that use watershed scales. For example, addressing the need to improve New York City's drinking water quality evolved from localized water-treatment options to a large-scale, watershed approach. This large-scale approach required the institution of land-management changes in Upstate New York necessary to maintain and improve New York City's drinking water quality.

While the concept of ecosystem services may seem relatively novel, market-based and other institutional approaches have been used in decision making for decades. These efforts include using auctions, trading, and taxes to address air, water, and carbon issues and to allocate scarce fishery resources. The institutional structures necessary to facilitate considering ecosystem services are continually evolving to address complex and regional issues. The result has been institutional structures with hybrid governance, public/private partnerships, and business/private partnerships. Watershed councils represent one early form of this evolution.

The institutional changes necessary to facilitate considering ecosystem services will require tools that are both market and non-market oriented. Market-based tools include taxes, cap and trade instruments, subsidies, and fees. Yet even these market-based instruments require regulation and a clearer sense of property rights and nuisance laws. The courts will play a key role in making these determinations. Non-market mechanisms include regulations and enforcement measures, including penalties for noncompliance. Information, education, and monitoring are necessary for both market and non-market-based approaches.

High-profile case studies demonstrate the potential benefits. These benefits can increase with continuing institutional evolution to meet changing markets and issues. Examples include the Conservation Reserve Program (CRP) to reduce soil erosion, wetland mitigation banking to address wetland losses, carbon trading to reduce global warming, and water banking to improve water quality and allocation. These programs use incentives to influence behavior and outcomes.

Institutional issues to be addressed include:

- Geographic and temporal scales for analyzing ecosystem services.

- The potential for ecosystem service markets to be created locally and extended globally.

- Consistency among Federal, State, and local laws concerning natural resources.

- Consideration of long-term consequences.

- Information sharing and cooperation among agencies.

- Internalizing externalities to take into account what has traditionally not been valued.

- Incorporating valuation of ecosystem services into the early stages of natural resource decision-making processes.

- Using ecosystem service values to coordinate and improve compliance with air, water, land, and other resource-related laws.

- Identifying and eliminating competing/conflicting regulations, policies, and market tools. 


\section{What would change if ecosystem services were routinely and effectively considered in conservation, restoration, resource management, and development decisions?}

Routine and effective use of ecosystem services information in decision making could have significant environmental, economic, and social consequences, resulting in more sustainable and resilient ecosystem processes for regulating air, water, and climate. Beyond simple carbon credits and satellite images, we envision a sophisticated worldwide system that accounts for ecosystem service outputs using an online database (for example, Google ecosystem services). Positive social effects include increased public awareness of the value of the natural capital that produces ecosystem services, and institutions flexible enough to take these values and functions into account. Human and ecosystem well-being could be effectively linked to decision making at local to global scales and environmental laws could explicitly consider natural capital and ecosystem services. Population centers could take on a more sustainable and lower impact structure. The positive economic effects would include allowing room for growth that does not interfere with basic ecosystem processes, ensuring inclusion of ecosystem services in market prices, allowing for payments to private landowners for producing ecosystem services, and recognizing values for aesthetic and cultural ecosystem services.

\section{Synthesis-How can ecology, economics, and geography be integrated so that ecosystem services are routinely and effectively used in decision making?}

Ecosystem services can be more effectively used in decision making if we:

- Develop improved methods for mapping and valuing ecosystem services.

- Understand the implications of using different geospatial units for ecosystem services mapping.

- Develop a standardized list of ecosystem services, allowing for regional flexibility and differences.

- Monitor and evaluate the effects of decisions on the quantity and value of ecosystem services.

- Use interdisciplinary research approaches.

- Include measures of uncertainty and risk in research and modeling results.

- Use case studies or pilot projects to demonstrate the usefulness of ecosystem services.

- Conduct cost-benefit analyses at multiple scales for projects affecting ecosystem services.

- Experiment to identify the relative viability of different incentive structures.

- Create “ecosystem services” performance standards for managers.

- Promote ecosystem services as key to human well-being and achieving sustainability goals (Millennium Ecosystem Assessment).

- Use existing extension and education agencies to improve public understanding of ecosystem services (incorporate ecosystem services into school books).

- Develop decision and communication tools for conveying information about ecosystem services to decision makers. 


\section{Appendix 1}

Preconference Workshop 1

Developing a Vision: Incorporating Ecosystem Services into Decision Making

Hosted by the MIT-USGS Science Impact Collaborative (MUSIC)

Massachusetts Institute of Technology, Cambridge, MA

April 15, 2008

Workshop held in association with

A Conference on Ecosystem Services (ACES)

ACES 2008: Using Science for Decision Making in Dynamic Systems

\section{Participants}

Greg Arthaud, Acting National Program Leader: Economics Research, U.S. Forest Service, Washington, DC

Rich Bernknopf, Economist, U.S. Geological Survey, Menlo Park, CA

Ronnie Best, Coordinator (Greater Everglades Science Program), U.S. Geological Survey, Fort Lauderdale, FL

Michael Bowers, National Program Leader, Ecology, Cooperative State Research, Education, \& Extension Service, U.S. Department of Agriculture, Washington, DC

Sandra Brewer, General Biologist, U.S. Army Corps of Engineers, Rock Island, IL

Rinku Roy Chowdhury, Assistant Professor, Geography and Regional Studies, University of Miami, Coral Gables, FL

Chip Euliss, Research Wildlife Biologist, U.S. Geological Survey, Jamestown, ND

Iris Goodman, Acting Deputy National Program Director for Ecology, U.S. Environmental Protection Agency, Washington, DC

Dave Goodrich, Research Hydraulic Engineer, ARS, Tucson, AZ

Tom Gunther, Program Coordinator, USGS Enterprise Information, and Project Lead for Data Integration and Interoperability, U.S. Geological Survey, Reston, VA

Paula Harrison, Senior Research Scientist, Centre for the Environment, Oxford University, Oxford, England

Abe Haspel, Assistant Deputy Secretary, U.S. Department of the Interior, Washington, DC 
Sharon Hayes, Policy Advisor to the Director, Gulf of Mexico Program Office, U.S. Environmental Protection Agency, Stennis Space Center, MS

Jim Henderson, Environmental Planner, U.S. Army Engineer Research and Development Center, U.S. Army Corps of Engineers, Vicksburg, MS

Dianna Hogan, Research Physical Scientist, U.S. Geological Survey, Reston, VA

Bea Van Horne, Ecosystem Program Coordinator, U.S. Geological Survey, Reston, VA

Bruce Jones, Chief Scientist for Geography, U.S. Geological Survey, Reston, VA

Herman Karl, Co-Director, MIT-USGS Science Impact Collaborative (MUSIC), and Visiting Lecturer Massachusetts Institute of Technology (MIT), Department of Urban Studies and Planning, Cambridge, MA

Carolyn Kousky, Doctoral Fellow, Kennedy School of Government, Harvard University, Cambridge, MA

Steve Light, Co-Director, Collaborative Adaptive Management Network (CAMNet), St. Paul, MN

Tran N Le, Graduate Student, Massachusetts Institute of Technology, Cambridge, MA (Meeting Recorder)

Jenny Liu, Senior Risk Specialist, DuPont Corporate Remediation Group, Wilmington, DE

Jerry McMahon, Research Geographer, U.S. Geological Survey, Raleigh, NC

Robert O'Connor, Program Director, Division of Social and Economic Sciences, National Science Foundation, Arlington, VA

Malka Pattison, Program Analyst, Office of Policy Analysis, U.S. Department of the Interior, Washington, DC

Deanna Reynolds, U.S. Geological Survey, Sioux Falls, SD (Meeting Facilitator)

Roger Sayre, Senior Scientist, Geographic Analysis and Monitoring Program, U.S. Geological Survey, Reston, VA

Darius Semmens, Research Physical Scientist, U.S. Geological Survey, Denver, CO

Carl Shapiro, Senior Advisor, Geography Discipline, U.S. Geological Survey, Reston, VA

Stephen Swallow, Professor, Environmental and Natural Resource Economics, University of Rhode Island, Kingston, RI 
Willie Taylor, Director, Office of Environmental Policy and Compliance, U.S. Department of the Interior, Washington, DC

Larry Tieszen, Project Chief Manager: Land Cover Applications, Landscape Dynamics, and Global Change, International Programs, U.S. Geological Survey, Sioux Falls, SD

Nathalie Valette-Silver, National Ocean Service Director for the Cooperative Center for Marine Animal Health, National Oceanic and Atmospheric Administration, Silver Spring, MD

Susan Wachter, Richard B. Worley Professor of Financial Management; Professor of Real Estate, Finance and City and Regional Planning, The Wharton School, University of Pennsylvania, Philadelphia, PA

Beth Williams, Graduate Student, Massachusette Institute of Technology, Cambridge, MA (Meeting Recorder)

Jim Wickham, Director, Multi-Resolution Land Characteristics Consortium (MRLC), U.S. Environmental Protection Agency, Research Triangle Park, NC 